\title{
Perancangan Sistem Pengamanan Data Video CCTV ATM (Anjungan Tunai Mandiri) Secara Diskrit dan Terdistibusi Menggunakan WLAN dan Sistem NAS
}

\section{Design of CCTV ATM (Automated Teller Machines) Video Data Security System Discrete and Distributed using WLAN and NAS Systems}

\author{
S I Lestariningati ${ }^{*}$, A Agusdian ${ }^{2}$ \\ 1)Program Studi Sistem Komputer, Fakultas Teknik dan Ilmu Komputer, Universitas Komputer Indonesia \\ Jl. Dipati Ukur No. 112 - 116, Bandung, Indonesia 40132 \\ 2)Sekolah Teknik Elektro dan Informatika, Institut Teknologi Bandung \\ Jl. Ganesha 10, Bandung, Indonesia 40132 \\ *email:susmini.indriani@email.unikom.ac.id
}

\begin{abstract}
In this paper it is designed discrete and distributed system to secure the CCTV video data on ATM (Automatic Teller Machine) or ATM sites. This new method is to cope with criminal action to ATM machines that usually together with action of vandalism to CCTV camera on ATM sites by criminals to destroy evidence of their actions, by proposed system the video data from CCTV is stored locally to hide small servers utilized WLAN and NAS system. The integrated camera transmitter and the NAS server are implemented using Raspberry Pi. The system passes all functional tests as designed, from data transmission test it is recommended to put $1 \mathrm{~m}$ to $7 \mathrm{~m}$ distance between NAS and Camera.
\end{abstract}

Keywords - ATM, CCTV, WLAN, NAS

ABSTRAK - Pada jurnal ini dirancang suatu sistem pengamanan data video CCTV (Closed Circuit Television) pada mesin ATM (Anjungan Tunai Mandiri) secara diskrit dan terdistribusi. Sistem ini dimaksudkan untuk mengamankan data video CCTV yang merekam jejak pelaku sebelum terjadi vandalisme terhadap perangkat CCTV, dimana data video disimpan pada perangkat yang tersembunyi di sekitar lokasi mesin ATM. Sistem terdiri dari perekam data dan pengirim data video kamera CCTV ke Server sistem NAS (Network Attached Storage) yang diimplementasikan menggunakan Raspberry Pi. Sistem transmisi data yang dipergunakan adalah jaringan WLAN (Wireless LAN). Sistem yang dirancang diuji secara fungsional berjalan sesuai perancangan dari hasil pengujian pengiriman data, server NAS dengan kamera dan pengirim datanya direkomendasikan ditempatkan dengan jarak antara $1 \mathrm{~m}$ hingga $7 \mathrm{~m}$.

Kata Kunci - al-Qur'an Player; Tunanetra; DFPlayer mini; Mikronkontroler ATMega128

\section{Pendahuluan}

Penggunaan CCTV pertama tercatat dalam sejarah adalah digunakan oleh Siemens AG pada Test Stand VII di Peenemünde, Nazi Jerman pada tahun 1942, untuk mengamati peluncuran roket V-2 [1]. CCTV kemudian pada perkembangannya dipakai lebih luas untuk keamanan termasuk untuk perbankan dimana dipasang pada kantor-kantor bank dan tempat ATM untuk merekam kegiatan, terutama untuk melacak kembali aksi perilaku kejahatan [2]. Analisa berbagai macam perilaku kejahatan yang tertangkap CCTV, termasuk kejahatan vandalisme terhadap mesin ATM, menunjukkan bahwa CCTV sangat efektif untuk mengungkapkan perilaku kriminal termasuk kepada mesin ATM [3].

Di Indonesia penyelenggara jasa ATM mengacu pada Peraturan Bank Indonesia No.18/15/PBI/2016 [4] penyelenggara jasa ATM digolongkan sebagai PJPU (Penyelengara Jasa Pengolahan Uang). PJPU diwajibkan untuk memberikan perlindungan keamanan terhadap konsumen, dimana hal ini 
dituangkan dalam Peraturan Bank Indonesia No.16/1/PBI/2014, termasuk keamanan transaksi hingga kemampuan untuk melacak kembali perilaku kejahatan pada mesin ATM. Berdasar Peraturan Bank Indonesia Nomor 18/40/PBI/2016 [5] untuk penyediaan fitur keamanan instrumen pembayaran dan atau transaksi pembayaran digolongkan sebagai Penyelenggara Penunjang termasuk untuk fitur keamanan untuk mesin ATM.

Saat ini penggunan CCTV pada Mesin ATM sudah menjadi standar yang didorong oleh ATMIA Asosiasi Industri Penyedia mesin ATM [6]. CCTV pada mesin ATM tersebut dipantau secara online melalui jaringan untuk keamanan konsumen [7], dimana data kamera dipantau dan direkam secara tersentralisasi pada suatu server. Hal ini dirasakan masih ada kelemahannya dikarenakan pelaku kriminal pada umumnya melakukan vandalisme terhadap kamera pada lingkungan ATM dengan tujuan untuk menghapus jejak perilaku kejahatannya.

Jaringan online ATM yang diperuntukkan untuk monitoring kamera video pada ATM tidak ekonomis jika selalu memantau atau merekam data kamera setiap saat [8], karena memerlukan bandwidth yang cukup besar, apalagi jika jaringan pemantauan kamera CCTV pada ATM tersebut terintegrasi dengan "secure high performance network" untuk transaksi ATM [9]. Begitu pula server penyimpanan data video yang tersentralisasi juga memerlukan investasi dan biaya operasi yang cukup tinggi misal ditempatkan pada suatu data centre yang memenuhi suatu standar teknis tertentu. Kedua faktor biaya ini pada akhirnya dapat meningkatkan ongkos layanan penggunaan ATM. Untuk membuat pemantauan kamera CCTV lebih ekonomis adalah memisahkan jaringan untuk transaksi ATM dengan jaringan untuk memantau kamera CCTV, dimana ini dapat berarti pemantauan akan melewati jaringan yang kurang dijamin kehandalannya. Penggunaan jaringan yang kurang dijamin kehandalannya ini berarti pula tidak ada jaminan bahwa selalu setiap saat ada rekaman data video CCTV dari tiap site mesin ATM pada server data yang tersentralisasi tersebut, dikarenakan rekaman atau pemantauan dapat hilang pada saat jaringan sedang tidak tersambung.

Pada Jurnal ini didesain suatu sistem pemantauan yang diskrit (tidak online) dan penyimpanan data video terdistribusi (tidak terpusat pada suatu data center) dimana pada setiap "sites" ATM terdapat mini server untuk penyimpanan data kamera CCTV secara otomatis dimana mini server tersebut dimaksudkan untuk disimpan pada tempat tersembunyi dan aman pada atau dekat "sites" mesin-mesin ATM dimana lebih terjamin keberadaan data video rekaman CCTV karena melewati jaringan lokal. Dengan sistem diskrit ini diharapkan ongkos bandwidth untuk pemantauan online CCTV dapat dikurangi dan bahkan dihilangkan dimana rekaman CCTV tetap dapat diakses secara efektif jika diperlukan, begitu pula ketidakhandalan jaringan untuk pemantauan secara online dapat dihindari. Begitu pula dengan sistim penyimpanan data video terdistribusi di masing-masing site dengan mini server yang biaya efektif dengan prosedur operasi yang lebih sederhana dimana setiap beberapa waktu berkala akan dihapus data video yang terekam bila tidak ada kasus.

\section{METODA DAN BAHAN}

Metoda untuk merancang sistem ini terdiri dari tahapan analisa kebutuhan, analisa fungsional serta alokasi bahan, dan sintesa perancangan [10] yang digambarkan pada gambar 1 .

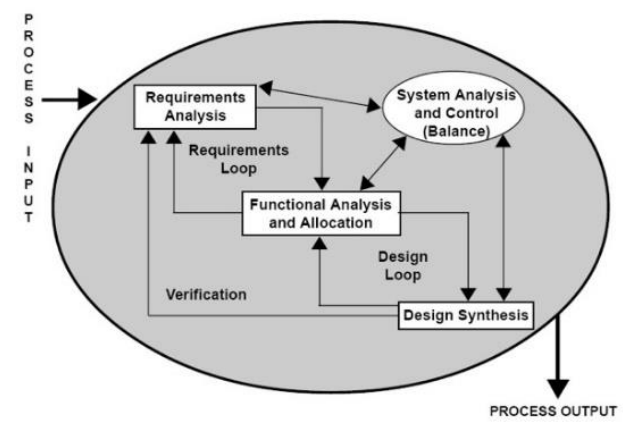

Gambar 1. Metoda Perancangan[10]

Fungsi-fungsi yang dibutuhkan untuk sistem yang dirancang dengan dikembangkan dari sistem pengamanan data video CCTV yang dikirim atau dimonitor secara sentralisasi, dengan ide menambahkan suatu perangkat server atau storage kecil yang dapat disembunyikan sekitar site dari mesin ATM.

Tabel 1. Analisa Kebutuhan dan Fungsi

\begin{tabular}{|c|c|c|}
\hline Fungsi & Kriteria & Alokasi \\
\hline $\begin{array}{l}\text { Kamer } \\
\text { a untuk } \\
\text { merekam } \\
\text { Data \& } \\
\text { Perangkat } \\
\text { Pengirim } \\
\text { Data-nya }\end{array}$ & $\begin{array}{l}\text { Resolusi pixel untuk } \\
\text { pengenalan wajah } \\
\text { Data dalam bentuk } \\
\text { standar yg dikenal } \\
\text { Bandwidth cukup } \\
\text { untuk menghantar sinyal } \\
\text { video } \\
\text { Mudah } \\
\text { diimplementasikan } \\
\text { Perangkat Mudah } \\
\text { disembunyikan } \\
\text { Konsumsi Daya } \\
\text { Rendah }\end{array}$ & \begin{tabular}{l}
\multicolumn{1}{c}{ Pi } \\
Kamera \\
sebagai \\
perekam dan \\
Raspberry \\
Pi+ modul \\
WLAN \\
sebagai \\
Pengirim \\
Data
\end{tabular} \\
\hline Media & Delay & WLAN \\
\hline
\end{tabular}




\begin{tabular}{lcl}
\hline $\begin{array}{l}\text { Pengirima } \\
\text { n Data }\end{array}$ & $\begin{array}{c}\text { mengganggu } \\
\text { Fleksibel } \\
\end{array}$ & \\
& Dapat diatur terhindar & \\
\multicolumn{1}{c}{ Perang } & Mudah & \multicolumn{1}{c}{ Raspberr } \\
katPeneri & disembunyikan & y Pi + modul \\
ma Data & Mudah dioperasikan & WLAN \\
\& & Mudah & sebagai \\
Storage- & diimplementasikan & receiver dan \\
nya & Aman dari intersepsi & SSD sebagai \\
& Konsumsi Daya & Data Storage \\
& Rendah & \\
\hline
\end{tabular}

Fungsi yang teridentifikasi sesuai kebutuhan adalah alat perekam video berupa kamera yang sekaligus terintegrasi dengan suatu alat pengirim data yang akan mengirim data ke penerima yang terintegrasi dengan storage sekitar tempat mesin ATM, yang tersambung melalui suatu jaringan media untuk pengiriman data. Pembagian fungsi, kriteria kebutuhan, dan alokasi bahan adalah terlihat seperti pada Tabel 1.

Kebutuhan kamera CCTV sebagai perekam data video diinginkan berukuran kecil agar mudah disembunyikan, tetapi mampu merekam gambar dengan resolusi yang baik untuk keperluan pengenalan pelaku kriminal atau vandalisme secara baik. Resolusi yang semakin tajam tentu semakin baik [11]. Kamera terpasang terintegrasi dengan alat perekam data video sekaligus berfungsi sebagai pengirim data kepada suatu perangkat penyimpan data.

Pengiriman data video ke server penyimpan data dapat melalui media wireless atau saluran transmini terbimbing seperti kabel [12]. Tetapi untuk keperluan menyembunyikan server penyimpanan data, maka tentu secara logis adalah menggunakan media atau sistem komunikasi wireless. Hal ini dikarenakan jika pengiriman data dilakukan dengan menggunakan kabel, maka pada kamera diambil dengan tujuan penghilangan jejak oleh pelaku kriminal, melalui penelusuran kabel dapat dicari sambungannya ke server penyimpan data tersembunyi tersebut, sehingga keberadaan alat atau perangkat ini dapat ditemukan oleh pelaku kejahatan, dengan kata lain tidak sesuai dengan rencana tujuan perancangan atas kebutuhan server penyimpan data tersembunyi.

Kebutuhan atas sistem komunikasi wireless dapat dilakukan dengan berbagai pilihan teknologi yaitu WLAN (Wireless Local Area Network), Bluetooth, Zigbee, NFC (Near Field Communication) ataupun Selular [13]. Adapun penggunaan telekomunikasi selular publik mungkin saja dilakukan [14], Pengiriman dengan sistem telekomunikasi selular publik akan ada tambahan biaya cukup besar.
Secara fleksibilitas dan kinerja dimana ketersediaan layanan termasuk bandwith, throughput, dan QoS (Quality of Services) tentu lebih baik jika menggunakan jaringan wireless lokal seperti WLAN atau Bluetooth, sementara untuk Zigbee atau NFC kurang cocok keperluan dari jarak dimana Zigbee dan NFC termasuk jenis PAN (Personal Area Network) yang didesain hanya efektif untuk penggunaan untuk jarak 1-2 meter.

Untuk jaringan wireless lokal sendiri perlu dipertimbangkan aspek keamanannya [15]. WLAN dipilih lebih baik dari pada bluetooh karena pada sistem WLAN bisa disetup lebih secure dibandingkan Bluetooth karena dapat memfilter MAC-address sehingga tidak bisa sembarangan alat bisa terkoneksi [16].

Sistem WLAN sendiri terdiri dari beberapa standard seperti dijelaskan pada Tabel 2 [17].

Tabel 2. Macam-macam WLAN 802.11 [17]

\begin{tabular}{|c|c|c|c|}
\hline $\begin{array}{l}\text { IEEE } \\
802.11 \\
\text { Protoc } \\
\text { ol }\end{array}$ & $\begin{array}{c}\text { Freque } \\
\text { ncy } \\
\text { Band } \\
\text { Ghz } \\
\end{array}$ & $\begin{array}{c}\text { Bandwidt } \\
\text { h(s) in } \\
\text { MHz }\end{array}$ & $\begin{array}{c}\text { Single } \\
\text { Stream } \\
\text { Rate(s) in } \\
\mathrm{Mb} / \mathrm{s}\end{array}$ \\
\hline $\begin{array}{c}\text { 802.11- } \\
1997\end{array}$ & 2.4 & 22 & 1,2 \\
\hline $11 a$ & 5 & 20 & $\begin{array}{c}6,9,12, \\
18,24, \\
36,48,54\end{array}$ \\
\hline $11 b$ & 2.4 & 22 & $\begin{array}{c}1,2,5.5 \\
11\end{array}$ \\
\hline $11 q$ & 2,4 & 20 & $\begin{array}{c}6,9,12, \\
18,24, \\
36,48,54\end{array}$ \\
\hline $11 n$ & $2.4 / 5$ & $20 / 40$ & Up to 150 \\
\hline $11 \mathrm{ac}$ & 5 & $\begin{array}{c}20 / 40 / 80 / 1 \\
60\end{array}$ & $\begin{array}{l}\text { Up to } \\
866,7\end{array}$ \\
\hline 11ad & 60 & 2160 & $\begin{array}{l}\text { Up to } \\
6757\end{array}$ \\
\hline 11ax & $2.4 / 5$ & Up to 1134 & $\begin{array}{l}\text { Up to } \\
1134\end{array}$ \\
\hline 11 ay & 60 & 8000 & $\geq 20 \mathrm{~Gb} / \mathrm{s}$ \\
\hline
\end{tabular}

Kebutuhan akan server penyimpanan (storage) tersembunyi dan juga dapat terkoneksi menerima data video kamera yang dikirimkan secara wireless dalam hal ini menggunakan sistem WLAN, dan kemudian menyimpannya dalam suatu penyimpanan data (database). Sistem penyimpanan data video tersebut dipilih menggunakan sistem NAS karena keperluan penyimpanan pada jaringan dan adanya fungsi file server dibanding SAN (Storage Area Network) [18].

Keseluruhan sistem ini didesain sebagai sistem berbasis komputer, dimana dalam implementasinya 
paling mudah adalah menggunakan Raspberry Pi, yang dipasang Pi Camera [19] untuk keperluan perekam data video dan sekaligus pengirimnya. Raspberry Pi adalah mini komputer ekonomis yang sangat populer dengan fitur yang dapat dipilih berdasarkan kebutuhan [20].

Raspberry $\mathrm{Pi}$ mempunyai OS yang berbasis Debian Linux dengan nama Raspbian dan terpasang bahasa pemrograman python untuk pengembangan aplikasi pada Raspberry termasuk merekam kamera. Varian Raspberry yang dipilih untuk pengembangan sistem ini adalah Raspberry Pi 3, hal ini disebabkan kebutuhan modul on-board wifi wireless LAN untuk pengiriman data video secara wireless dan sekaligus kebutuhan kamera dalam hal ini dipakai Pi Camera [21] untuk keperluan fungsi perekam data video, dimana kedua hal tersebut dapat disediakan oleh Raspberry Pi 3. Sistem operasi bawaan Raspberry Pi 3 adalah Raspbian Stretch. Pada gambar 3 merupakan komponen dari Raspberry Pi.

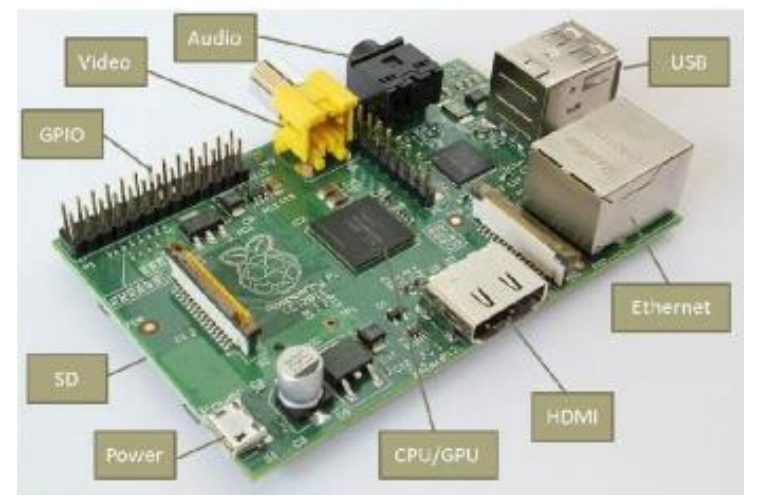

Gambar 2. Raspberry Pi [20]

Data video yang direkam dikodekan dengan H.264 oleh Raspberry Pi, pemilihan pengkodean H.264 ini didapat dengan cara men-setting Raspberry Pi [22], dan sekaligus kemudian data video yang terkodekan H.264 tersebut dikirimkan melalui modul WLAN yang memang onboard pada Raspberry Pi.

Sementara untuk penerima dan sekaligus berfungsi sebagai server mini penyimpan data video juga digunakan Raspberry Pi 3 yang disambungkan dengan suatu SSD (solid state drive) [23] melalui konektor USB 3 pada Raspberry Pi dimana SSD dikonfigurasi sebagai boot drive [24].

Sistem NAS pada server mini ini dapat diimplementasikan dengan 2 (dua) cara yaitu mengkonfigurasi samba protokol dan ssh ftp [25], atau cara yang lebih mudah dengan menginstall OMV (Open Media Vault) Linux Distro, sebagai Operating System dan kemudian meng-enable fitur Samba/CFIS (Common Internet File System), dimana fungsi storage dan file server sekaligus dapat diaktifasi [26].
Sebagai server NAS, Raspberry Pi pada server penyimpan data yang berfungsi sebagai penerima data terkoneksi dengan sistem WLAN dengan perangkat perekam data \& pengirim datanya. Dimana server penyimpan data ini juga dikonfigurasi sebagai AP (Access Point) sekaligus server DHCP, dengan setting MAC Address filtering untuk keamanan akses [27].

Desain Sistem Pengamanan Data Video CCTV secara diskrit dan terdistribusi Pemilihan bahan berdasarkan kehandalan, kemudahan penggunaan, dan kemudahan pengembangan yang mempengaruhi faktor ekonomis. Sistem akan diuji fungsi-fungsinya sesuai perancangannya dan akan pula pengukuran kinerja sistem secara simulasi untuk pengujian fungsi sekaligus menentukan batasan spesifikasi teknis dari sistem.

\section{HASIL DAN PEMBAHASAN}

Diagram Blok Sistem yang didesain dan disintesa terdiri dari Client, Media transmisi, dan Server, yang digambarkan pada gambar 3 .

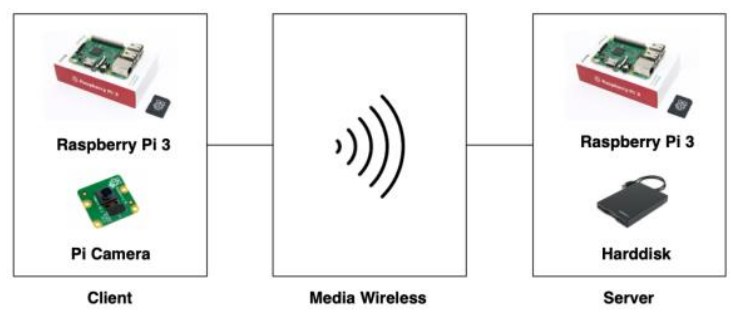

Gambar 3. Blok Diagram Sistem

Blok Client terdiri dari Pi Camera dan Board Raspberry Pi 3 yang saling menyatu atau terintegrasi. Pi Camera berfungsi untuk menangkap atau mengcapture video sekaligus kemudian video tersebut direkam oleh Raspberry Pi dengan standar codec H.264 disimpan sementara pada memory Raspberry Pi dalam bentuk file. Data video H.264 dalam bentuk file tersebut dikirim oleh Client kepada Server mini penyimpan data melalui Media Transmisi wireless atau nirkabel.

Blok Media Transmisi dalam hal ini udara atau ruang bebas media tempat merambatnya data yang dikirim oleh pengirim ke penerima. Sistem Protokol yang dipergunakan untuk pengiriman adalah Wireless LAN IEEE 802.11, yang juga terdiri dari berbagai macam jenis protokol yang berkembang sesuai perkembangan teknik telekomunikasi. Jenis yang dipilih pada Raspberry Pi 3 adalah Wireless LAN $802.11 \mathrm{~g}$

Blok Server terdiri dari Raspberry Pi yang terintegrasi dengan suatu SSD (Solid State Drive). Kedua perangkat tersebut secara kesatuan berfungsi sebagai suatu NAS (Network Attached Storage) 
dalam suatu network atau jarigan dalam hal ini Wireless LAN, dimana Blok Server adalah suatu mini server yang berfungsi menyimpan data video H.264 yang dikirim oleh Blok Client, sekaligus mengelola file tersebut dalam suatu sistem penyimpanan file. Sesuai dengan fungsi Server mini NAS tersebut, maka sistem WLAN (Wireless LAN) di Blok Server sekaligus dikonfigurasi sebagai WLAN AP (Access Point) dan juga server DHCP untuk mempermudah akses pengiriman dari Blok Client dan juga untuk mempermudah akses untuk pengelolaan data atau file jika pengguna datang ke site. Pengelolaan data file oleh user ini adalah untuk keperluan mengambil data file video yang diperlukan sekaligus menghapus data file video secara berkala agar storage tidak menjadi penuh. Spesifikasi perangkat keras dan lunak untuk sistem dapat dilihat pada Tabel 3.

Tabel 3. Spesifikasi Perangkat

\begin{tabular}{|c|c|}
\hline Peragkat & Spesifikasi \\
\hline Pi Camera & $\begin{array}{l}\text { Dimensi } 25 \times 24 \times 9 \mathrm{~mm} \\
\text { Resolusi } 5 \mathrm{Mpixels} \text { : } 2592 \times 1944 \mathrm{pxl} \\
1.4 \mu \mathrm{m} \times 1.4 \mu \mathrm{m} \\
\text { Dynamic range 67dB @ 8xgain } \\
\text { Sensitivity } 680 \mathrm{mV} / \mathrm{lux}-\mathrm{sec} . \text { Dark } \\
\text { currnent } 16 \mathrm{mV} / \mathrm{sec} @ 60 \mathrm{C} \\
\text { Focal length } 3.60 \mathrm{~mm}+/-0.0 . \mathrm{R}(\mathrm{F}- \\
\text { Stop) } 2.9 \\
\text { Focus } 1 \mathrm{~m}-\infty . \text { Full-frame SLR lens } \approx \\
35 \mathrm{~mm} \\
\text { View: V } 41.41+/-0.11 . \mathrm{H} 53.50+/- \\
0.13 \text { (degrees) } \\
\text { Codec H.264 30FPS Full HD }\end{array}$ \\
\hline $\begin{array}{c}\text { Raspberry } \\
\text { Pi3 }\end{array}$ & $\begin{array}{l}\text { Broadcom BCM2837 ARM Cortex } \\
\text { Quad Core 1.2GHz, 1GB RAM } 4 \text { x } \\
\text { USB ports } \\
\text { Onboard IEEE } 802.11 \mathrm{~b} / \mathrm{g} / \mathrm{n} \text { WLAN } \\
\text { OS Debian Linux Based Raspbian } \\
\text { Strech } \\
\text { NAS NFS- Open Media Vault: FTP } \\
\text { SMB DAAC } \\
\text { Dimenssion: } 85.60 \mathrm{~mm} \times 56.5 \mathrm{~mm} \times \\
17 \text { mm } \\
\text { Power: idle } 200 \mathrm{~mA}(1.5 \mathrm{~W}), \text { Max } \\
1.34 \text { A }(6.7 \mathrm{~W})\end{array}$ \\
\hline $\begin{array}{l}\text { SSD (Solid } \\
\text { State Drive) }\end{array}$ & $\begin{array}{l}\text { Capacity/Actual Capacity } \\
\text { 120GB/111.79GB SATAIII (6Gb/s), } \\
\text { Controller PS3109-S9 MLC NAND } \\
\text { flash. } \\
2.5^{\circ .} . \text { Dim: } 100 \mathrm{~mm} \text { x } 69.85 \mathrm{~mm} \mathrm{x} \\
6.90 \mathrm{~mm} \\
\text { MTBF : 1,000,000 hrs } \\
\text { Sequential Read/Write Speed (6Gb/s) }\end{array}$ \\
\hline
\end{tabular}

Pi Camera pada client mempunyai spesifikasi yang sangat baik untuk keperluan CCTV untuk identifikasi perilaku kejahatan bila dibandingkan dengan keperluan praktisnya [28], dengan resolusi kisaran 5Mega Pixels, dengan ukuran per-pixel yang sangat tajam $1.4 \mu \mathrm{m} \times 1.4 \mu \mathrm{m}$ memungkinkan pembesaran gambar yang sangat tajam untuk pengenalan wajah pelaku kriminal,ditambah lagi fokus mulai dari $1 \mathrm{~m}$, dynamic range yang lebar, dan view vertikal-horizontal yang efektif untuk menangkap kegiatan pada suatu site, dalam hal ini site ATM. Pada client Pi Camera dipasang dan diintegrasikan dengan Raspberry $\mathrm{Pi} 3$ untuk merekam gambar video dengan keluaran codec H.264, dimana Codec H.264 ini adalah codec yang cukup untuk keperluan CCTV dimana tidak terlalu menghasilkan file yang terlalu besar pada resolusi Full HD, tetapi masih bisa dikompresi lagi jika diperlukan [29]

Versi Rasberry Pi yang digunakan pada sistem ini adalah Raspberry Pi 3 atau kadang disebut juga sebagai Raspberry Pi 3B. Pada Raspberry 3B ini dikembangkan secara khusus Broadcom BCM2837 system-on-chip (SoC) mencakup empat core pemrosesan ARM Cortex-A53 yang berperforma tinggi pada clock $1.2 \mathrm{GHz}$ dengan memori cache $32 \mathrm{kB}$ Level 1 dan 512kB Level 2. Processing Unit dari versi ini mempunyai kinerja yang lebih baik dari pendahulunya, berdasarkan pengujian Dhrystone (MIPS), Wheatstone (MWIPS), maupun Sysbench (secs), hal ini dapat dilihat seperti pada Tabel 4 [30].

Tabel 4. Hasil Perbandingan Kinerja Board CPU Rasberry $\mathrm{Pi}[30]$

\begin{tabular}{|c|c|c|c|c|}
\hline \multicolumn{2}{|c|}{ BOARD } & $\begin{array}{l}\text { Dhrystone } \\
\text { (MIPS) }\end{array}$ & $\begin{array}{l}\text { Whetstone } \\
\text { (MWIPS) }\end{array}$ & $\begin{array}{l}\text { Sysbench } \\
\text { CPU (sec) }\end{array}$ \\
\hline \multicolumn{2}{|c|}{ Model B+ } & 847.1 & 232.558 & 510.8 \\
\hline \multicolumn{2}{|c|}{ Model A+ } & 863.2 & 236.858 & 502.4 \\
\hline \multicolumn{2}{|c|}{ Zero } & 1237.3 & 340.498 & 349.4 \\
\hline \multirow{2}{*}{$\begin{array}{l}\mathbf{P i} \\
2\end{array}$} & S-T & 1671.6 & 437.212 & 293.1 \\
\hline & M-T & & & 76.28 \\
\hline \multirow{2}{*}{$\begin{array}{l}\mathbf{P i} \\
3\end{array}$} & S-T & 2458.1 & 711.363 & 182.2 \\
\hline & M-T & & & 49.02 \\
\hline
\end{tabular}

Chip Broadcom BCM43438 juga menyediakan sistem komunikasi WLAN $802.11 \mathrm{~b} / \mathrm{g} / \mathrm{n} 2.4 \mathrm{GHz}$ onboard untuk menekan biaya, serta antena yang tersolder sercara onboard juga, sehingga tidak diperlukan eksternal antena lagi. Terlepas dari ukurannya yang kecil, antena ini sangat mampu menangkap sinyal wireless LAN bahkan bisa menembus dinding [30].

Pada Raspberry Pi di client terinstall OS Raspbian yang merupakan modifikasi dari Debian Linux 
untuk Raspberry. Sementara untuk mini Server penyimpan data, Raspberry Pi 3 disambung ke SSD (Solid State Drive) USB to SATA 3 (sequential read/write speed 6Gbps), terinstal sistem operasi Open Media Vault sebagai sistem NAS. Kapasitas SSD yang terpasang dalam simulasi sistem adalah 120GB, jika besar file yang terekam untuk 2 menit dengan codec H.264 sekitar 100MB dari catatan hasil perekaman, maka jumlah file yang dapat tersimpan pada server adalah sekitar 1000 file video, tentu ini sangat tergantung dari lama video direkam dan seberapa sering terjadi perekaman serta berapa besar kapasitas SSD. Pada prosedur operasionalnya tentu diperlukan petugas keliling yang menghapus file tersebut jika SSD sudah hampir penuh, dengan mengkopi files sebelumnya sebelum dihapus. SSD yang dipergunakan mempunyai MTBF 1,000,000 hours yang artinya sangat handal tidak perlu diganti sepanjang pemakaian.

Dimensi blok client yang terdiri dari Raspberry Pi dan Pi kamera cukup kecil sekitar $8 \times 6 \mathrm{~cm}$, sementara untuk server mini ukuran lebih besar karena ukuran SSD yang lebih besar sekitar 10x7 cm. Kedua ukuran perangkat secar fisik cukup kecil dan masuk dalam kategori mudah untuk disembunyikan.

Konsumsi daya dari kedua perangkat adalah maksimum 6.7 Watt mengikuti maksimum konsumsi daya Raspberry Pi, karena perangkat Pi Camera maupun SSD dicatu oleh Raspberry Pi. Konsumsi daya ini cukup kecil bahkan sebanding dengan sebuah lampu LED penerang ruangan ATM, yang dimana dalam ruangan ATM biasanya terdapat lebih dari 1(satu) lampu penerangan. Sehingga tidak menambah biaya konsumsi daya yang signifikan.

Fungsi-fungsi sistem yang akan diujikan adalah sebagai berikut:

Pengujian perekaman data video pada kamera

Pengujian kualitas pengiriman data video melalui media wireless ke server. Pada pengiriman data ini selain kualitas pengiriman juga akan ditinjau delay dan throughput dari sistem wireless untuk mengetahui efektifitas sistem WLAN

Pengujian pengolahan data video pada server yang sudah tersimpan dalam server sistem storage, meliputi proses pengambilan data, proses penghapusan data, dan sorting atau pengurutan data.

Pengujian fungsi perekaman data pada video kamera menghasilkan beberapa jenis ukuran video yang berbeda 19MB-1000 MB, hal ini dikarenakan data video yang direkam hasil simulasi bergantung lama aksi seseorang untuk melakukan transaksi pada mesin ATM. Secara teknis lama aksi perekaman ini dikonversikan dalam besaran file adalah 50MB untuk rekaman sekitar 1(satu) menit [31].

Pada pengujian kualitas pengiriman data menggunakan tools alat bantu software Wireshark, untuk proses Capture Data, memiliki delay dan throughput yang berbeda-beda tergantung ukuran data video yang dikirim dan kualitas transmisi wireless LAN pada saat pengiriman. Pada Tabel 5 dijelaskan hasil dari pengujian kualitas pengiriman data.

Tabel 5. Pengujian Kualitas Pengiriman Data

\begin{tabular}{ccccc}
\hline \multirow{1}{*}{$\begin{array}{c}\text { Nama } \\
\text { Sampel }\end{array}$} & $\begin{array}{c}\text { Video27-07- } \\
\text { Data } \\
\text { 2018_09-01 }\end{array}$ & $\begin{array}{c}\text { Delay } \\
(\mathbf{m s})\end{array}$ & $\begin{array}{c}\text { Throughput } \\
\text { (Mbps) }\end{array}$ \\
\hline $\mathbf{2}$ & $\begin{array}{c}\text { Video27-07- } \\
\text { 2018_09-02 }\end{array}$ & 335 & 48.56 & 23.58 \\
\hline $\mathbf{3}$ & $\begin{array}{c}\text { Video27-07- } \\
\text { 2018_09-03 }\end{array}$ & 371 & 75.91 & 22.58 \\
\hline $\mathbf{4}$ & $\begin{array}{l}\text { Video27-07- } \\
\text { 2018_09-04 }\end{array}$ & 453 & 54.38 & 41.89 \\
\hline $\mathbf{5}$ & $\begin{array}{l}\text { Video27-07- } \\
\text { 2018_09-05 }\end{array}$ & 570 & 42.73 & 47.75 \\
\hline $\mathbf{6}$ & $\begin{array}{l}\text { Video27-07- } \\
\text { 2018_09-06 }\end{array}$ & 677 & 88 & 21.24 \\
\hline $\mathbf{7}$ & $\begin{array}{l}\text { Video27-07- } \\
\text { 2018_09-07 }\end{array}$ & 766 & 80.88 & 23 \\
\hline $\mathbf{8}$ & $\begin{array}{l}\text { Video27-07- } \\
\text { 2018_09-08 }\end{array}$ & 909 & 72.28 & 24.64 \\
\hline $\mathbf{9}$ & $\begin{array}{l}\text { Video27-07- } \\
\text { 2018_09-09 }\end{array}$ & 1026 & 79.49 & 24.97 \\
\hline $\mathbf{1 0}$ & $\begin{array}{l}\text { Video27-07- } \\
\text { 2018_09-10 }\end{array}$ & 1139 & 84.87 & 25 \\
\hline \multirow{2}{*}{ Rata-Rata } & & $\mathbf{7 0 . 1 3}$ & $\mathbf{2 6 . 4 4}$ \\
\hline
\end{tabular}

Delay adalah waktu tunda saat paket yang disebabkan oleh proses pengiriman dari satu tujuan terhadap tujuannya. Proses ini dilihat dari selisih waktu kirim antara satu paket dengan paket lainnya. Untuk menghitung rata-rata delay digunakan rumus: [32].

$$
\text { Delay Rata }- \text { rata }=\frac{\text { Total Delay }}{\text { Total paket yang diterima }}
$$

Tabel 5. Kategori Delay [32]

\begin{tabular}{lcc}
\hline $\begin{array}{c}\text { Kategori } \\
\text { Latensi }\end{array}$ & Besar Delay $(\mathrm{ms})$ & Indeks \\
\hline Sangat Bagus & $<150 \mathrm{~ms}$ & 4 \\
\hline Bagus & $150 \mathrm{~ms} \mathrm{~s} / \mathrm{d} 300 \mathrm{~ms}$ & 3 \\
\hline Sedang & $300 \mathrm{~ms} \mathrm{~s} / \mathrm{d} 450 \mathrm{~ms}$ & 2 \\
\hline Jelek & $>450 \mathrm{~ms}$ & 1 \\
\hline
\end{tabular}


Throughput adalah kecepatan pengiriman data, kemudian diukur dalam satuan bps. Throuhput merupakan jumlah total paket yang datang dengan sukses, yang diamati pada tujuan selama waktu tertentu dibagi oleh durasi waktu tersebut [32]. Rumus Throughput yang digunakan:

$$
\text { Throughput }=\frac{\text { Paket yang diterima }}{\text { Lama Pengamatan }}
$$

Tabel 6. Kategori Throughput [31]

\begin{tabular}{lcc}
\hline \multicolumn{1}{c}{ Kategori } & Throughput & Indeks \\
\hline Sangat Bagus & $100 \%$ & 4 \\
\hline Bagus & $75 \%$ & 3 \\
\hline Sedang & $50 \%$ & 2 \\
\hline \multicolumn{1}{c}{ Jelek } & $<\mathbf{2 5 \%}$ & $\mathbf{1}$ \\
\hline
\end{tabular}

Dari hasil dari sampel data pada Tabel 6, yang diambil dari beberapa kali pengujian pengiriman data menggunakan media transmisi wireless LAN didapatkan nilai rata-rata delay dan throughput dari sistem pengiriman data kamera video dari pengirim ke server penerima. Nilai rata-rata delay adalah 70.13 ms yang artinya mempunyai delay yang masuk dalam katagori sangat baik untuk pengiriman data [32].

Pada simulasi sistem ini mode pengiriman WLAN Raspberry Pi 3 secara default adalah 802.11g yang mempunyai data link rate maksimum 54 Mbps tergantung orde modulasinya. Throughput rata-rata yang didapat dari hasil pengujian adalah $26.44 \mathrm{Mbps}$ sekitar 50\% dimana angka tersebut menunjukan dalam katagori sedang dalam sebuah sistem pengiriman data [32]. Pengukuran dilakukan pada suatu ruangan laboratorium dimana jaraknya masih masuk dimana data link rate dapat menghasilkan mode maksimum $54 \mathrm{Mbps}$ yaitu pada jarak kira-kira dibawah $30 \mathrm{~m}$ indoor. Throughput sekitar $50 \%$ dalam praktek adalah sangat wajar karena adanya noise dan interferensi pada unlincence band WLAN $2.4 \mathrm{GHz}$.

Pada pengujian proses pengolahan data yang menggunakan sistem Samba dilakukan dengan menggunakan terminal yang sudah terhubung dengan Raspberry Pi server yang sudah mendapatkan User dan Password yang sudah di kofigurasi sebelumnya. Dalam pengolah data pada sistem ini server dapat diakes oleh perangkat petugas mesin ATM yang terhubung dengan wireless dan mempunyai hak akses User dan Password yang sudah dikonfigurasi sebelumnya, sehingga pengguna dapat melakukan pengolahan data berupa pengambilan data merubah nama data ataupun menghapus data yang sudah tidak digunakan untuk menambah ruang penyimpanan.
Pada sistem ini juga dilakukan pengamanan konfigurasi pada akses Wireless LAN tetapi tidak dilakukan pendalaman secara khusus tentang ini dikarenakan pengamanan Wireless LAN tersebut sudah merupakan hal yang sangat umum.

\section{KESIMPULAN}

Sistem pengamanan data video kamera CCTV pada ATM atau sites ATM secara diskrit dan terdisitribusi teruji dapat berfungsi dengan sesuai dengan perancangannya dengan menggunakan sistem NAS yang tersembunyi dimana data video dikirim dan diakses melalui media sistem WLAN.

Dari hasil perekaman video besar data video bervariasi tergantung durasi dari lama perekaman, hal ini akan menjadi faktor untuk menghitung kebutuhan besarnya storage NAS yang diperlukan dengan juga menentukan frekuensi proses pengolahan data oleh petugas ke site.

Berdasarkan pengujian fungsi pengiriman data melalui single server WLAN, delay maupun througput merekomendasikan penempatan pada jarak umum 1-30 meter indoor antara client perekam data dan Server mini penyimpan data.

Pada kamera CCTV dapat diterapkan pula suatu algoritma pendektesian gerakan objek manusia untuk meningkatkan efektifitas perekaman data pada kamera CCTV, atau juga dapat diterapkan suatu metoda kompresi data video CCTV untuk maksud yang sama, tetapi kedua hal ini tidak menjadi bahasan pada Jurnal ini.

\section{UCAPAN TERIMA KASIH}

Ucapan terima kasih diberikan kepada seluruh asisten dan mahasiswa yang terlibat di Data Communication and Computer Networks.

\section{DAFTAR PUSTAKA}

[1] T. Dornberger, Walter; Cleugh, James and Halliday, Geoffrey, V-2. Ballantine Books, New York, 1954.

[2] B. C. of K. L. \& W. Norfolk, “CCTV." [Online]. Available:

https://web.archive.org/web/20090523184010 /http://www.west-

norfolk.gov.uk/default.aspx?page $=21697$. [Accessed: 18-Feb-2019].

[3] G. Alexandrie, "Surveillance cameras and crime: a review of randomized and natural experiments," J. Scand. Stud. Criminol. Crime Prev., vol. 18, no. 2, pp. 210-222, Jul. 2017.

[4] D. C. Syamsir and E. Sarvia, "Perancangan Mesin ATM dan Ruangan ATM Berdasarkan 
Ilmu Ergonomi ( Studi Kasus di ATM ' Bank A ' Setrasari, Bandung ) The Design of ATM Machine and ATM Room Based on Ergonomics ( Case Study on ' Bank A' ATM Setrasari , Bandung )," pp. 34-51.

[5] B. Indonesia, "PBI 18/40/PBI/2016 Penyelenggaraan Pemrosesan Transaksi Pembayaran," p. 51, 2016.

[6] F. Hayashi, R. J. Sullivan, and S. E. Weiner, Guide to the ATM and Debit Card Industry: 2006 Update. 2006.

[7] K. J. Hole, T. Tjøstheim, V. Moen, L. Netland, and Y. Espelid, "REPORTS IN Next Generation Internet Banking in Norway Department of Informatics," 2008.

[8] K. Hooda, "ATM Security," Int. J. Sci. Res. Publ., vol. 6, no. 4, pp. 159-163, 2016.

[9] N. Sharma, "Vulnerability and security issues in Auto teller machine transactions," Natl. Conf. Secur. Data Commun. Networks, 2011.

[10] Anonym, "Systems Engineering Fundamentals Supplementary Text Prepared By the Defense Acquisition University Press Fort Belvoir, Virginia 22060-5565," no. January, 2001.

[11] N. Cohen, J. Gattuso, and K. MacLennan-Brown, "CCTV Operational Requirements Manual 2009," Home Office Scientific Developmenr Branch, 2009. [Online]. Available: http:/ / science.homeoffice.gov.uk/hosdb/\%5C nii.

[12] W. Stalling, Data and Computer Communications. Pearson, 2014.

[13] A. F. Molisch, Wireless Communication. John Wiley \& Sons Ltd, 2011.

[14] G. Miao, J. Zander, K. W. Sung, and S. Ben Slimane, Fundamentals of mobile data networks. Cambridge University Press, 2016.

[15] S. Plosz, A. Farshad, M. Tauber, C. Lesjak, T. Ruprechter, and N. Pereira, "Security vulnerabilities and risks in industrial usage of wireless communication," 19th IEEE Int. Conf. Emerg. Technol. Fact. Autom. ETFA 2014, no. September, 2014.

[16] W. Osterhage, Wireless Network Security, 2nd ed. CRC Press.

[17] C. Links, "Wi-Fi Data Rates , Channels and Capacity years, the IEEE," no. December 2017, pp. 1-8.

[18] "An Introduction to Network Attached Storage," SPH Magazines, pp. 90-92, 2003.
[19] V. Menezes, V. Patchava, and M. S. D. Gupta, "Surveillance and monitoring system using Raspberry Pi and SimpleCV," in 2015 International Conference on Green Computing and Internet of Things (ICGCIoT), 2015, pp. 1276-1278.

[20] S. Singh, P. Anap, Y. Bhaigade, and P. J. P. Chavan, "IP Camera Video Surveillance using Raspberry Pi," Ijarcce, vol. 4, no. 2, pp. 326-328, 2015.

[21] M. Richardson and S. Wallace, Make: Getting Started with Raspberry Pi, 3rd Editio. San Franscisco, CA: Maker Media, 2016.

[22] U. Jennehag, S. Forsstrom, and F. Fiordigigli, "Low Delay Video Streaming on the Internet of Things Using Raspberry Pi," Electronics, vol. 5, no. 4, p. 60, 2016.

[23] P. Bednar and V. Katos, "SSD: New Challenges for Digital Forensics," ItAIS 2011, Proc. 8th Conf. Ital. Chapter Assoc. Inf. Syst., no. September, pp. 1-8, 2011.

[24] B. Upton, Eben; Duntemann, Jeffrey; Roberts, Ralph; Mamtora, Tim; Everard, Learning Computer Architecture with Raspberry Pi. 2016.

[25] I. Kandov, "Experimental model of Low Power NAS and Cloud drive based on Raspberry Pi," Balk. J. Electr. Comput. Eng., vol. 3, no. 1, pp. 2-4, 2015.

[26] V. Theile, “Open Media Vault Documentation Release4.0.0." [Online]. Available: https://www.openmediavault.org. [Accessed: 18-Feb-2019].

[27] Lady Ada, “Setting up a Raspberry Pi as a WiFi Access Point." [Online]. Available: https:/ / learn.adafruit.com/setting-up-araspberry-pi-as-a-wifi-access-point. [Accessed: 18-Feb-2019].

[28] N. Name, "Closed Circuit Television Specification Guidelines," 2018.

[29] Y. Joskin, "The Right Video Compression for Digital CCTV," 2008.

[30] The MagPi Magazine, "Raspberry Pi 3 is out now! Specs, benchmarks \& more," The MagPi Magazine, 2016.

[31] J. Ostermann et al., "Video coding with H.264/AVC: tools, performance, and complexity," IEEE Circuits Syst. Mag., vol. 4, no. 1, pp. 7-28, 2004.

[32] M. N. O. Sadiku and S. M. Musa, Performance analysis of computer networks. Springer International Publishing, 2013. 